\title{
LYST Gene Mutation
}

National Cancer Institute

\section{Source}

National Cancer Institute. LYST Gene Mutation. NCI Thesaurus. Code C158655.

A change in the nucleotide sequence of the LYST gene. 